\title{
Antibacterial Activity of the Red Algae Eucheuma cottonii Extract from Tanjung Coast, Sumenep Madura
}

\author{
Zulli Andriani, A. Ghanaim Fasya, Ahmad Hanapi \\ Jurusan Kimia Fakultas Sains dan Teknologi Universitas Islam Negeri Maulana Malik Ibrahim Malang \\ Email : zulliandriani@gmail.com
}

\begin{abstract}
Red alge Euchema cottonii is one of the biological source that has benefits. The aim of this study is to determine the effectiveness of antibacterial red algae Eucheuma cottonii extract. Isolation of active compounds was performed by maceration method using methanol. The methanol extract was hydrolyzed using $\mathrm{HCl} 2 \mathrm{~N}$ and partitioned by ethyl acetate, chloroform, petroleum ether and $n$-hexane solvents. The antibacterial assessment was determined using disc diffusion method againts bacteria Staphylococcus aureus and Escherichia coli. Identification of active compound was conducted by reagents test. The results showed that the best solvent to extract algae was methanol with $20.7 \%$ rendemen. The methanol extract $4 \%$ gives the highest inhibition at concentrations was $7.85 \mathrm{~mm}$; followed by $n$-hexane and chloroform were 1.0 and $0.6 \mathrm{~mm}$. However, bath ethyl acetate and petroleum ether extract depicted no inhibition zone. The identification test showed the presence of flavonoids, triterpenoids, steroids and alkaloids in the methanol extract. The extract of n-hexane contained triterpenoids and alkaloids, while the chloroform extract contained flavonoids, triterpenoids and alkaloids.
\end{abstract}

Keywords: Euchema cottonii, antibacterial, disc diffusion

\begin{abstract}
Abstrak
Alga merah Eucheuma cottonii merupakan salah satu sumber daya hayati yang memiliki banyak manfaat. Pada penelitian ini akan dilakukan pengujian aktivitas antibakteri terhadap ekstrak alga merah. Ekstraksi senyawa aktif dilakukan dengan metode maserasi menggunakan pelarut metanol. Ekstrak metanol dihidrolisis dengan $\mathrm{HCl} 2 \mathrm{~N}$ dan dipartisi dengan variasi pelarut etil asetat, kloroform, petroleum eter dan $n$-heksana. Uji antibakteri menggunakan metode difusi cakram terhadap bakteri Staphylococcus aureus dan Escherichia coli. Identifikasi golongan senyawa aktif dengan uji reagen dan diamati secara kualitatif. Hasil penelitian menunjukkan bahwa metanol merupakan pelarut terbaik untuk mengekstrak senyawa aktif alga merah dengan rendemen 20,7 \%. Ekstrak kasar metanol memiliki zona hambat tertinggi pada konsentrasi 4\% sebesar 7,85 mm, $n$-heksana sebesar $1 \mathrm{~mm}$ dan kloroform sebesar $0,6 \mathrm{~mm}$. Hasil identifikasi golongan senyawa aktif alga merah yang memiliki aktivitas antibakteri menunjukkan bahwa ekstrak metanol mengandung flavonoid, triterpenoid, steroid dan alkaloid. Ekstrak $n$-heksana mengandung triterpenoid dan alkaloid, sedangkan ekstrak kloroform mengandung flavonoid, triterpenoid dan alkaloid.
\end{abstract}

Kata kunci: Euchema cottonii, antibakteri, difusi cakram

\section{Pendahuluan}

Indonesia merupakan negara maritim karena hampir $70 \%$ luas wilayahnya berupa lautan. Di dalam laut terdapat bermacammacam makhluk hidup baik yang berupa tumbuhan air maupun hewan air (Afrianto dan Liviawati, 1993). Salah satu sumber daya hayati yang cukup potensial dari perairan laut Indonesia adalah rumput laut dengan berbagai macam jenisnya. Penyebaran rumput laut terdapat hampir di seluruh perairan Indonesia. Rumput laut banyak yang hidup di atas karang-karang terjal yang melindungi pantai dari deburan ombak di daerah pantai dibagian selatan Jawa dan pantai barat Sumatera.

Pembagian jenis alga merah (Rhodophyceae) antara lain Gracilaria gigas, Gelidium latifolium, Eucheuma spinosum, Eucheuma cottonii dan lain sebagainya. Alga merah Eucheuma cottonii telah diketahui berpotensi menghasilkan karaginan yang dapat dimanfaatkan untuk berbagai macam produk (Poncomulyo, 2006). Seiring dengan perkembangan sains dan teknologi, rumput laut telah ditingkatkan pemanfaatanya sehingga memberikan nilai ekonomi yang lebih 
tinggi. Salah satu pemanfaatanya adalah sebagai antimikroba, antikanker dan pestisida.

Karaginan merupakan senyawa polisakarida yang dihasilkan dari beberapa jenis alga merah yang memiliki sifat antibakteri, antiinflamasi, antipiretik, antikoagulan dan aktivitas biologis lainnya. Aktivitas antibakteri pada karaginan yang dihasilkan oleh alga merah jenis Condrus crispus. Selain itu, alga merah juga diduga mengandung senyawa metabolit sekunder yang dapat menghasilkan aktivitas antibakteri (Shanmugam \& Mody, 2002 dalam Iskandar, dkk., 2005). Selain itu, Iskandar, dkk., (2005) juga menyatakan bahwa ekstrak etanol alga merah $E$. cottonii mempunyai aktivitas terhadap bakteri Echerichia coli dan Bacillus cereus.

Pada penelitian ini, uji antibakteri dilakukan secara in vitro terhadap bakteri Staphylococcus aureus dan E. coli dengan pertimbangan bahwa $S$. aureus merupakan bakteri gram-positif, sedangkan E. coli merupakan bakteri gram-negatif. Aktivitas antibakteri diuji menggunakan metode cakram dan pengenceran agar. Menurut Kumala dan Desi (2009) keuntungan menggunakan metode cakram adalah jumlah larutan zat yang terserap dapat diatur sesuai dengan kapasitas cakram, selain itu juga tergantung dari diameter serta ketebalan cakram.

Penelitian ini bertujuan untuk menentukan pelarut terbaik dalam mengekstrak senyawa aktif alga merah $E$. cottonii. Selain itu, dilakukan penentuan aktivitas antibakteri dan golongan senyawa ekstrak alga merah E. cottonii.

\section{Metode Penelitian}

\subsection{Alat dan Bahan}

Alat yang digunakan dalam penelitian ini adalah neraca analitik (Mettler AE 25), seperangkat alat gelas, rotary evaporator, shaker, inkubator, autoklaf, dan pipet mikro. Bahan utama yang digunakan adalah alga merah E. cottonii, $S$. aureus dan $E$. coli. Bahan lain yang digunakan adalah metanol, etil asetat, kloroform, petroleum eter, $n$-heksana, etanol $95 \%$, media NA (Nutrient Agar) dan NB (Nutrient broth).

\subsection{Uji Taksonomi}

Alga merah diuji taksonomi di Laboratorium Biologi Universitas Negeri Maulana Malik Ibrahim Malang.

\subsection{Preparasi Sampel}

Alga merah dicuci dan dikeringkan dengan menggunakan oven pada suhu 37$38^{\circ} \mathrm{C}$. Alga merah kering dihaluskan dan diayak dengan ukuran 60-250 mesh.

\subsection{Analisis Kadar Air}

Cawan dipanaskan dahulu dalam oven pada suhu $105^{\circ} \mathrm{C}$ sekitar 15 menit, kemudian disimpan dalam desikator selama 10 menit. Cawan ditimbang dan ditentukan beratnya. Perlakuan tersebut dilakukan hinggadiperoleh berat cawan yang konstan. Alga merah kering dimasukkan ke dalam cawan. Alga merah sebanyak 5 gram dikeringkan dalam oven pada suhu $105^{\circ} \mathrm{C}$ selama \pm 15 menit dan disimpan dalam desikator sekitar \pm 10 menit serta ditimbang. Perlakuan ini diulangi sampai beratnya konstan. Kadar air dalam rumput laut dihitung menggunakan rumus berikut.

Kadar air $=\frac{(b-c)}{(b-a)} \times 100 \%$

Dimana a adalah berat konstan cawan kosong, $b$ adalah berat cawan+sampel sebelum dikeringkan, dan c adalah berat konstan cawan+sampel setelah dikeringkan.

\subsection{Analisis Kadar Garam}

Lima gram alga merah ditambah 10$20 \mathrm{~mL}$ akuades. Campuran tersebut diaduk dan ditunggu sehingga semua garam $(\mathrm{NaCl})$ larut, selanjutnya disaring dengan vacum Buchner. Proses ini diulang sebanyak 5 kali dan filtrat ditampung. Kadar garam diukur menggunakan salinometer Atago PAL-06S 
refraktometer (Sudarmadji, dkk., 2007). Analisis kadar garam dilakukan pada alga merah kering dan basah.

\subsection{Ekstraksi Sampel}

Serbuk alga merah sebanyak 300 gram direndam dalam $900 \mathrm{~mL}$ metanol (Hukmah, 2007) dan diaduk menggunakan shaker dengan kecepatan $120 \mathrm{rpm}$ selama 24 jam (Hartini, 2004). Setelah itu, disaring dan ampas yang diperoleh dimaserasi kembali sebanyak dua kali. Ekstrak alga merah dipekatkan dengan rotary evaporator vacum dan diperoleh ekstrak pekat.

Ekstrak pekat dibagi menjadi dua, yaitu ekstrak A digunakan untuk proses ekstraksi cair-cair dan ekstrak B digunakan untuk uji aktivitas antibakteri. Ekstrak A dihidrolisis dengan menambahkan $10 \mathrm{~mL}$ $\mathrm{HCl} 2 \mathrm{~N}$ dan diaduk selama 1 jam (Tensiska, dkk., 2007). Hidrolisat yang diperoleh ditambahkan larutan $\mathrm{NaHCO}_{3} 5 \%$ sampai netral, lalu diekstraksi cair-cair menggunakan pelarut etil asetat, kloroform, petroleum eter dan $n$-heksana dengan perbandingan 1:1. Hasil dari ekstraksi caircair dipekatkan dengan rotary evaporator vacum dan dihitung nilai rendemen.

\subsection{Uji Aktivitas Antibakteri}

Ekstrak B digunakan untuk uji aktivatas antibakteri. Ekstrak dibuat dalam berbagai variasi dengan rentang 0,5-4\%. Kontrol positif yang digunakan adalah streptomosin $6,25 \quad \mathrm{mg} / \mathrm{mL} \quad(0,625 \quad \%)$ digunakan untuk bakteri Staphylcoccus aureus dan penisilin $25 \mathrm{mg} / \mathrm{mL}(2,5 \%)$ untuk bakteri E. coli (Soetan, dkk., 2006). Uji antibakteri dilakukan menggunakan metode difusi cakram. Kertas cakram dimasukkan dalam larutan kontrol positif (penisilin dasn streptomisin) dan larutan ekstrak (metanol, etil asetat, kloroform, petroleum eter, dan n-heksana). Kertas cakram diletakkan pada media padat yang mengandung bakteri. Media yang berisi bakteri dibuat dengan mencairkan media padat dan menambahkan $0,1 \mathrm{~mL}$ biakan bakteri. Setelah itu, sampel diinkubasi pada suhu $37{ }^{\circ} \mathrm{C}$ selama 24 jam dan diukur zona hambatnya. Luas zona hambatan ditentukan dengan cara mengurangi diameter keseluruhan (cakram + zona hambatan) dengan diameter cakram dan diameter zona hambatan pelarut (jika pelarut member zona hambatan).

\subsection{Identifikasi Golongan Senyawa Aktif dengan Uji Reagen \\ 2.8.1 Uji Flavonoid}

Ekstrak alga merah dimasukkan ke dalam tabung reaksi kemudian dilarutkan dalam 1-2 $\mathrm{mL}$ metanol panas $50 \%$. Setelah itu, ditambah logam $\mathrm{Mg}$ dan 4-5 tetes $\mathrm{HCl}$ pekat. Larutan berwarna merah atau jingga yang terbentuk, menunjukkan adanya flavonoid (Indrayani dkk., 2006).

\subsubsection{Uji Triterpenoid/Steroid}

Ekstrak alga merah ditambahkan 0,5 $\mathrm{mL}$ kloroform. Selanjutnya, ditambahkan dengan $0,5 \mathrm{~mL}$ asam asetat anhidrat. Kemudian, ditambahkan 1-2 mL larutan $\mathrm{H}_{2} \mathrm{SO}_{4}$ pekat melalui dinding tabung reaksi. Terbentuk cincin kecoklatan atau violet pada pembatas dua pelarut menunjukkan adanya golongan senyawa triterpenoid dalam sampel (Indrayani dkk., 2006).

\subsubsection{Uji Alkaloid}

Ekstrak alga merah dimasukkan ke dalam tabung reaksi, ditambah $0,5 \mathrm{~mL} \mathrm{HCl}$ $2 \%$ dan larutan dibagi dalam dua tabung. Tabung I ditambahkan 2-3 tetes reagen Dragendorff, tabung II ditambahkan 2-3 tetes reagen Mayer. Jika tabung I terbentuk endapan jingga dan pada tabung II terbentuk endapan kekuning-kuningan, menunjukkan adanya alkaloid (Indrayani dkk., 2006).

\subsection{Analisis Data}

Data yang diperoleh berupa nilai diameter zona hambat hasil uji aktivitas antibakteri dilakukan dengan menggunakan uji anova. 


\section{Hasil dan Pembahasan}

\subsection{Uji Taksonomi}

Berdasarkan hasil penelitian didapatkan ciri-ciri sampel alga merah sebagai berikut: alga berwarna kuning kecoklatan, talus bercabang banyak selangseling, berbentuk silindris, berdaging dan agak kaku dengan duri-duri yang mencuat kesamping dan permukaan yang licin. Oleh karena itu, disimpulkan bahwa sampel merupakan alga merah E. cottonii.

\subsection{Preparasi Sampel}

Sampel yang digunakan dalam penelitian ini adalah alga merah $E$. cottonii yang diperoleh dari Pantai Tanjung Sumenep. Sampel dikeringkan untuk menurunkan kadar air. Pengeringan dilakukan pada suhu $37-38{ }^{\circ} \mathrm{C}$ bertujuan menghindari kerusakan senyawa aktif. Penghalusan dilakukan dengan tujuan memperluas permukaan sampel, sehingga mempermudah kontak antara pelarut dan sampel pada saat ekstraksi maserasi. Setelah dilakukan penghalusan sampel disaring menggunakan ayakan dengan ukuran 60250 mesh.

\subsection{Analisis Kadar Air}

Analisis kadar air dimaksudkan untuk mengetahui kandungan air dalam alga merah. Kadar air sangat berpengaruh terhadap daya simpan sampel. Perhitungan kadar air sampel ditunjukkan pada Tabel 1.

Tabel 1. Perhitungan kadar air pada alga merah E. cottonii

\begin{tabular}{cc}
\hline Alga merah & Kadar air (\%) \\
\hline Basah & 88,1 \\
Kering & 5,76 \\
\hline
\end{tabular}

Sampel basah memiliki rata-rata kadar air yang tinggi yaitu $88,1 \%$. Santoso (2004) menyebutkan bahwa alga memiliki kadar air sebesar 83,3 \%. Hal ini sesuai dengan Winarno (1990) yang menyatakan bahwa kandungan utama alga segar adalah air yang mencapai 80-90 \%. SNI 01-02690 (1992) menetapkan kadar air alga merah kering untuk E. cottonii maksimum $35 \%$. Kadar air pada sampel kering rata-rata sebesar $5,76 \%$ sehingga kadar air yang diperoleh dari penelitian ini masih memenuhi standar mutu rumput laut kering.

\subsection{Analisis Kadar Garam}

Kadar garam pada suatu perairan berperan penting bagi organisme laut terutama dalam mengatur tekanan osmosis yang ada dalam tubuh organisme dengan cairan lingkungannya. Kadar garam pada sampel kering lebih besar dibandingkan dengan sampel basah. Hal ini dikarenakan kandungan air dalam sampel telah menguap sehingga meningkatkan kandungan garam dalam sampel tersebut, sebagaimana ditunjukkan pada Tabel 2.

Tabel 2. Analisis kadar garam alga merah $E$. cottonii

\begin{tabular}{cc}
\hline Alga merah & Kadar garam $(\boldsymbol{\%})$ \\
\hline Basah & 6,00 \\
Kering & 31,5 \\
\hline
\end{tabular}

\subsection{Ekstraksi Sampel}

Ekstraksi alga merah dilakukan menggunakan metode maserasi dengan pelarut methanol. Ekstrak pekat hasil maserasi dihidrolisis menggunakan $\mathrm{HCl}$. Hidrolisis bertujuan untuk memisahkan antara senyawa glikon dan aglikon pada senyawa glikosida. Ekstrak hidrolisis diekstraksi kembali mengggunakan partisi dengan berbagai pelarut dengan tingkat kepolaran yang berbeda.

Tabel 3. Rendemen ekstrak pada masingmasing pelarut

\begin{tabular}{ccc}
\hline \multirow{2}{*}{ Ekstrak } & \multicolumn{2}{c}{ Rendemen (\%) } \\
\cline { 2 - 3 } & $\begin{array}{c}\text { Per g ekstrak } \\
\text { kasar }\end{array}$ & Per g sampel \\
\hline Metanol & 100 & 20,7 \\
$n$-Heksana & 12,1 & 2,50 \\
Petroleum & 16,6 & 3,44 \\
eter & 9,17 & 1,90 \\
Kloroform & 34,7 & 7,17 \\
Etil asetat & & \\
\hline
\end{tabular}


Rendemen tertinggi yang diperoleh dari hasil ekstraksi cair-cair terdapat pada ekstrak etil asetat yaitu 7,17 \%. Hal ini dimungkinkan karena dalam alga merah E. cottonii terkandung banyak senyawa yang bersifat semi polar.

\subsection{Uji Aktivitas Antibakteri}

Uji aktivitas antibakteri merupakan metode pengujian yang dilakukan untuk mengetahui kemampuan suatu bahan dalam menghambat pertumbuhan bakteri. Pengujian ini dilakukan terhadap bakteri $S$. aureus (gram positif) dan bakteri E. coli (gram negatif) secara in vitro dengan metode difusi cakram. Penentuan efektivitas antibakteri dilakukan berdasarkan diameter zona hambat yang muncul di sekitar cakram yang berisi zat antibakteri. Semakin luas zona hambat yang terbentuk maka semakin efektif zat tersebut sebagai antibakteri. Hasil uji menujukkan bahwa ekstrak methanol memiliki aktivitas tertinggi yang diikuti dengan ekstrak n-heksana dan kloroform. Hal ini mengindikasikan bahwa antibakteri pada algamerah cenderung bersifat polar.

Tabel 4. Hasil uji efektivitas antibakteri terhadap bakteri S. aureus

\begin{tabular}{cccccc}
\hline \multirow{2}{*}{ Konsentrasi \% (b/v) } & \multicolumn{5}{c}{ Bakteri S. aureus $(\mathbf{m m})$} \\
\cline { 2 - 6 } & Metanol & $\boldsymbol{n}$-Heksana & Petroleum eter & Kloroform & Etil asetat \\
\hline 0,5 & 1,58 & - & - & - & - \\
1 & 1,75 & - & - & - & - \\
2 & 2,33 & - & - & 0,330 & - \\
3 & 5,00 & - & - & 0,330 & - \\
4 & 7,85 & - & - & 0,600 & - \\
Kontrol negatif & - & - & Streptomisin $=15,6$ & - & - \\
Kontrol positif 0,625 & & &
\end{tabular}

Tabel 5. Hasil uji efektivitas antibakteri terhadap bakteri E. coli

\begin{tabular}{cccccc}
\hline \multirow{2}{*}{ Konsentrasi \% $(\mathbf{b} / \mathbf{v})$} & \multicolumn{5}{c}{ Bakteri $\boldsymbol{E}$. coli $(\mathbf{m m})$} \\
\cline { 2 - 6 } & Metanol & $\boldsymbol{n}$-Heksana & Petroleum eter & Kloroform & Etil asetat \\
\hline 0,5 & 1,08 & - & - & - & - \\
1 & 2,75 & - & - & - & - \\
2 & 2,91 & - & - & - & - \\
3 & 3,00 & 0,33 & - & 0,33 & - \\
4 & 6,25 & 1 & - & 0,60 & - \\
Kontrol negatif & - & - & - & - & - \\
Kontrol positif 2,5 & & \multicolumn{5}{c}{ Penisilin $=6,75$} \\
\hline
\end{tabular}

Zona hambat yang dihasilkan dari uji terhadap bakteri $S$. aureus lebih besar daripada bakteri E. coli. Hal tersebut dimungkinkan karena struktur dinding sel bakteri $S$. aureus yang berlapis tunggal, tersusun atas peptidoglikan (protein dan gula) dan lipid dengan kadar rendah (1-4\%) sehingga mudah ditembus oleh senyawa pada ekstrak metanol. Sedangkan struktur dinding sel bakteri $E$. coli berlapis tiga, tersusun atas peptidoglikan dan lipid dengan kadar yang tinggi (11-22\%) sehingga sulit untuk ditembus oleh seyawa pada ekstrak metanol.
Kandungan metabolit sekunder berpotensi sebagai antibakteri pada ekstrak alga merah E. cottonii yaitu flavonoid, triterpenoid, steroid dan alkaloid terutamanya pada ekstrak metanol. Menurut Farouk, dkk. (2007), metabolit sekunder lain yang berpotensi sebagai senyawa antibakteri adalah senyawa steroid, triterpenoid dan alkaloid. Golongan senyawa tersebut mengandung polisakarida sehingga dapat menembus membran sel bakteri.

Konsentrasi suatu ekstrak juga dapat berpengaruh terhadap aktivitas antibakteri. 
Berdasarkan hasil uji pada Tabel 4 dan Tabel 5 menunjukkan bahwa semakin besar konsentrasi suatu ekstrak maka semakin besar pula aktivitas antibakteri. Aktivitas antibakteri ditandai dengan terbentuknya zona hambat yang besar. Semakin besar zona hambat, semakin besar aktivitas sampel dalam menghambat pertumbuhan bakteri. Efektivitas antibakteri terbaik ditunjukkan ekstrak metanol alga merah pada konsentrasi $4 \%$.

\subsection{Identifikasi Senyawa Aktif dengan Uji Reagen}

Identifikasi senyawa merupakan tahapan awal untuk mengetahui golongan senyawa yang terkandung dalam alga merah E. Cottonii. Identifikasi dilakukan pada ekstrak metanol, n-heksana dan klooform. Prinsip kerja uji reagen didasarkan perubahan warna oleh suatu pereaksi warna, dimana perubahan warna tersebut dicocokkan dengan standar warna yang ada.

Tabel 6 menunjukkan bahwa metabolit sekunder pada ekstrak metanol yaitu flavonoid, triterpenoid, steroid dan alkaloid. Sedangkan etil asetat mengandung steroid dan alkaloid. Hal ini didukung oleh Widyawati (2011), metanol efektif untuk mengekstrak senyawa polar, seperti flavonoid, fenolik dan saponin. Sedangkan Shofiatun (2012) menjelaskan bahwa ekstrak metanol dan etil asetat mengandung saponin, steroid dan triterpenoid. Berbeda dengan metabolit sekunder pada ekstrak kloroform yaitu flavonoid, triterpenoid dan alkaloid yang didukung dengan penelitian Husna (2009) yang juga melaporkan bahwa ekstrak kloroform mengandung alkaloid, sedangkan ekstrak metanol mengandung saponin, steroid dan alkaloid.

\subsection{Analisis Data}

Hasil uji aktivitas antibakteri yang menghasilkan zona hambat yaitu pada ekstrak metanol, $n$-heksana dan kloroform terhadap bakteri $S$. aureus dan E. Coli. Analisis zona hambat dilakukan menggunakan ANOVA satu arah. Tujuannya adalah untuk menguji perbedaan rerata perlakuan yang telah dilakukan.

Berdasarkan Tabel 7 hasil uji BNT rata-rata zona hambat terhadap bakteri $S$. aureus menunjukkan perlakuan pada konsentrasi $4 \%$ merupakan nilai rata-rata tertinggi. Hal ini menunjukkan bahwa konsentrasi tersebut merupakan konsentrasi terbaik dalam menghambat bakteri.

Tabel 6. Hasil identifikasi senyawa aktif $E$. cottonii

\begin{tabular}{lccc}
\hline \multirow{2}{*}{ Golongan Senyawa } & \multicolumn{3}{c}{ Pelarut } \\
\cline { 2 - 4 } & Metanol & $\boldsymbol{n}$-Heksana & Kloroform \\
\hline Flavonoid & ++ & - & + \\
Triterpenoid & ++ & + & + \\
Steroid & + & - & - \\
Alkaloid & - & - & + \\
a) Dragendrof & + & + & + \\
b) Mayer & &
\end{tabular}

Keterangan: Tanda $++=$ terkandung senyawa lebih banyak (warna lebih pekat)

Tanda $+=$ terkandung senyawa (berwarna)

Tanda $-\quad=$ tidak terkandung senyawa

Sedangkan berdasarkan Tabel 8 hasil uji BNT rata-rata zona hambat terhadap bakteri E. coli menunjukkan perlakuan pada konsentrasi $4 \%$ merupakan nilai rata-rata tertinggi dengan notasi huruf yang berbeda. Hal ini menunjukkan bahwa konsentrasi ini merupakan konsentrasi yang baik pada penghambatan bakteri tersebut. Namun jika dibandingkan dengan kontrol penisilin pada konsentrasi $4 \%$ ekstrak metanol menunjukkan notasi yang sama. Hal ini menunjukkan bahwa ekstrak tersebut tidak mempunyai beda nyata secara signifikan. Perbedaan yang ditimbulkan hanya beda 
ALCHEMY: Journal of Chemistry, Vol. 4 No. 2 Oktober 2015, hal 93-100

tipis di bawah kontrol, sehingga pada seefektif kontrol penisilin 2,5\%.

konsentrasi tersebut mempunyai potensi

Tabel 7. Hasil uji BNT variasi konsentrasi ekstrak terhadap zona hambat S. aureus

\begin{tabular}{ccc}
\hline \multirow{2}{*}{ Konsentrasi } & \multicolumn{2}{c}{ Diameter zona hambat } \\
\cline { 2 - 3 } & Metanol & Kloroform \\
\hline Kontrol Negatif (pelarut) & $0,000^{\mathrm{a}}$ & $0,000^{\mathrm{a}}$ \\
$0,5 \%$ & $1,58^{\mathrm{a}}$ & $0,000^{\mathrm{a}}$ \\
$1 \%$ & $1,75^{\mathrm{a}}$ & $0,000^{\mathrm{a}}$ \\
$2 \%$ & $2,33^{\mathrm{ab}}$ & $0,333^{\mathrm{a}}$ \\
$3 \%$ & $5,00^{\mathrm{b}}$ & $0,333^{\mathrm{a}}$ \\
$4 \%$ & $7,83^{\mathrm{c}}$ & $0,667^{\mathrm{a}}$ \\
Streptomisin $0,625 \%$ & $15,6^{\mathrm{d}}$ & $15,4^{\mathbf{b}}$ \\
\hline $\boldsymbol{F}_{\text {hitung }}$ & $\mathbf{3 3 , 8}$ & $\mathbf{2 9 6}$ \\
\hline
\end{tabular}

Tabel 8. Hasil uji BNT variasi konsentrasi ekstrak terhadap zona hambat E. coli

\begin{tabular}{cccc}
\hline \multirow{2}{*}{ Konsentrasi } & \multicolumn{3}{c}{ Diameter zona hambat } \\
\cline { 2 - 4 } & Metanol & Kloroform & $\boldsymbol{n}$-Heksana \\
\hline Kontrol Negatif (pelarut) & $0,000^{\mathrm{a}}$ & $0,000^{\mathrm{a}}$ & $0,000^{\mathrm{a}}$ \\
$0,5 \%$ & $1,08^{\mathrm{ab}}$ & $0,000^{\mathrm{a}}$ & $0,000^{\mathrm{a}}$ \\
$1 \%$ & $2,75^{\mathrm{b}}$ & $0,000^{\mathrm{a}}$ & $0,000^{\mathrm{a}}$ \\
$2 \%$ & $2,92^{\mathrm{b}}$ & $0,000^{\mathrm{a}}$ & $0,000^{\mathrm{a}}$ \\
$3 \%$ & $3,00^{\mathrm{b}}$ & $0,333^{\mathrm{a}}$ & $0,333^{\mathrm{a}}$ \\
$4 \%$ & $6,25^{\mathrm{c}}$ & $0,667^{\mathrm{a}}$ & $1,00^{\mathrm{b}}$ \\
Penisilin 2,5 \% & $6,75^{\mathrm{c}}$ & $6,75^{\mathrm{b}}$ & $6,75^{\mathrm{c}}$ \\
\hline $\boldsymbol{F}_{\text {hitung }}$ & $\mathbf{1 0 , 6}$ & $\mathbf{1 0 6}$ & $\mathbf{1 4 6}$ \\
\hline
\end{tabular}

\section{Kesimpulan}

Pelarut terbaik untuk mengekstrak senyawa aktif antibakteri pada alga merah E. cottonii adalah metanol. Ekstrak metanol yang paling efektif sebagai antibakteri pada konsentrasi $4 \%$ terhadap pertumbuhan bakteri $S$. aureus dengan zona hambat sebesar 7,85 mm dan E. coli sebesar 6,25 $\mathrm{mm}$. Adapun golongan senyawa aktif yang memiliki aktivitas antibakteri dalam ekstrak kasar metanol adalah senyawa flavonoid, triterpenoid, steroid dan alkaloid. Ekstrak $n$ heksana mengandung triterpenoid dan alkaloid, sedangkan ekstrak kloroform mengandung flavonoid, triterpenoid dan alkaloid.

\section{Daftar Pustaka}

Afrianto E., dan Liviawati, E. 1993. Budi Daya Rumput Laut dan Cara Pengolahannya. Jakarta: Bhratara.

Farouk, A.E., Faizal A.H.G., dan Ridzwan B.H.. 2007. New Bacterial Species Isolated from Malaysian Sea Cucumbers with Optimized Secreted Antibacterial Activity. American Journal of Biochemistry and Biotechnology, Vol. 3 (2): 60-65.

Hartini, S.Y. 2004. Daya Antibakteri Campuran Ekstrak Etanol Buah Adas Etanol Buah Adas (Foeniculum vulgare Mill) dan Kulit Batang Pulasari (Alyxia reinwardtii BL). Jurnal Penelitian Fakultas Farmasi, Vol. 2: 34-35. 
ALCHEMY: Journal of Chemistry, Vol. 4 No. 2 Oktober 2015, hal 93-100

Hukmah, S. 2007. Aktivitas Antioksidan Katekin dari Teh Hijau (Camellia Sinensis O.K. Var. Assamica (mast)) Hasil Ekstraksi dengan Variasi Pelarut dan Suhu. Skripsi Tidak Diterbitkan. Universitas Islam Negeri Malang, Malang.

Husna, M. 2009. Identifikasi Senyawa Ekstrak Etil Asetat Tanaman AntingAnting (Acalypha indica Linn) dan Uji Aktivitas Antimalaria in Vivo pada Hewan Uji. Skripsi Tidak Diterbitkan. Universitas Islam Negeri Malang, Malang.

Indrayani, L., Soetjipto, H. dan Sihasale, L. 2006. Skrinning Fitokimia dan Uji Toksisitas Ekstrak Daun Pecut Kuda (Stachytarpheta jamaicensis L. Vahl) Terhadap Larva Udang Artemia salina Leach. Skripsi Tidak Diterbitkan. Universitas Kristen Satya Wacana, Salatoga.

Iskandar, Y., Rusmiati, D. dan Rini, R.D. 2005. Uji Aktivitas Antibakteri Ekstrak Etanol Rumput Laut (Eucheuma cottonii) Terhadap Bakteri Escherichia coli dan Bacillus cereus. Jurusan Farmasi Fakultas MIPA Universitas Padjadjaran, Bandung.

Kumala, S. dan Desi. 2009. Aktivitas Antibakteri Ekstrak Daun Ilerb (Coleus atropuspureus Benth) terhadap Beberapa Bakteri Gram (+) dan Bakteri Gram (-). Skripsi Tidak Diterbitkan. Jurusan Farmasi Fakultas Universitas Pancasila, Jakarta.
Poncomulyo, T. 2006. Budi Daya dan Pengolahan Rumput Laut. Jakarta: AgroMedia Pustaka.

Santoso. 2004. Kesehatan dan Gizi. Jakarta: Rineka Cipta.

Shofiatun, N. 2012. Uji Bioaktivitas Ekstrak Teripang Pasir (Holothuria scabra) Terhadap Bakteri Pseudomonas aeruginosa dan Bacillus cereus. Skripsi Tidak Diterbitkan. Universitas Diponegoro, Semarang.

Soetan, K., Oyekunle, M., Aiyelaagbe, O., dan Fafunso, M. 2006. Evaluation of The Antimicrobial Activity of Saponins Extract of Sorgum Bicolor L. Moench, African Journal of Biotechnology, Vol. 5 (23): 2405-2407

Sudarmadji, S., Haryono, B. dan Suhardi. 2007. Prosedur Analisa Bahan Makanan dan Pertanian. Yogyakarta: Liberty.

Tensiska, Marsetio, dan Yudiastuti, S.O.N. 2007. Pengaruh Jenis Pelarut Terhadap Aktivitas Antioksidan Ekstrak Kasar Isoflavon Dari Ampas Tahu. Skripsi Tidak Diterbitkan. Universitas Padjadjaran, Bandung.

Widyawati, P. S. 2011. Aktivitas Antioksidan Ekstrak Metanolik Daun Beluntas (Pluchea indica Less) dan Fraksinya serta Kemampuan Mencegah Warmed Over Flavor pada Daging Itik yang telah Dipanaskan. Tesis Tidak Diterbitkan. Institut Pertanian Bogor, Bogor.

Winarno, F. G. 1990. Teknologi Pengolahan Rumput Laut. Jakarta: Sinar Pustaka. 